\title{
Author Correction: Synthetic RNA-based logic computation in mammalian cells
}

Satoshi Matsuura ${ }^{1,2}$, Hiroki Ono ${ }^{1,2}$, Shunsuke Kawasaki ${ }^{1}$, Yi Kuang $^{1,3}$, Yoshihiko Fujita ${ }^{1}$ \& Hirohide Saito (iD ${ }^{1}$

Correction to: Nature Communications https://doi.org/10.1038/s41467-018-07181-2, published online 19 November 2018

The original version of this Article contained an error in the fourth sentence of the second paragraph of the 'Improving the performance of miRNA-responsive circuits' section of the Results, which incorrectly read 'We confirmed a significant fold-change between ON and OFF states (from 3.5- to 9.0-fold) in 293FT cells (Supplementary Figure 3).' The correct version states '4.6' in place of ' 3.5 '. This has been corrected in both the PDF and HTML versions of the Article.

The original version of the Supplementary Information contained a corresponding error in Supplementary Figure 3. The correct version of Supplementary Figure 3 is:
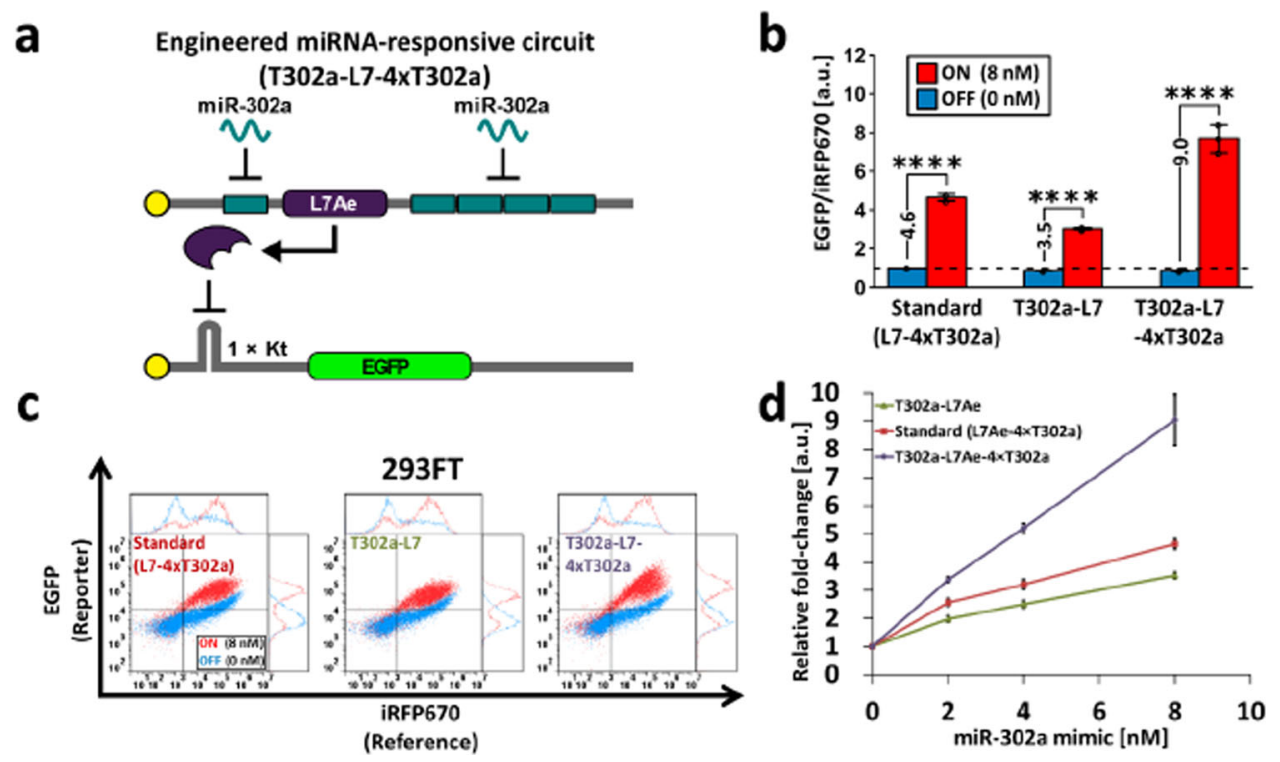

\footnotetext{
${ }^{1}$ Department of Life Science Frontiers, Center for iPS Cell Research and Application (CiRA), Kyoto University, Kyoto 606-8507, Japan. ${ }^{2}$ Graduate School of Medicine, Kyoto University, Kyoto 606-8501, Japan. ${ }^{3}$ Present address: Department of Chemical and Biological Engineering, Hong Kong University of Science and Technology, Clear Water Bay, Hong Kong, SAR, China. Correspondence and requests for materials should be addressed to H.S. (email: hirohide. saito@cira.kyoto-u.ac.jp)
} 


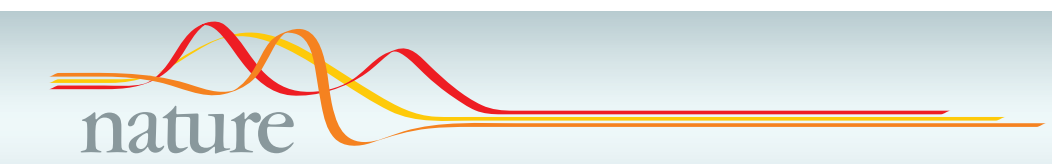

\title{
COMMUNICATIONS
}

which replaces the previous incorrect version:
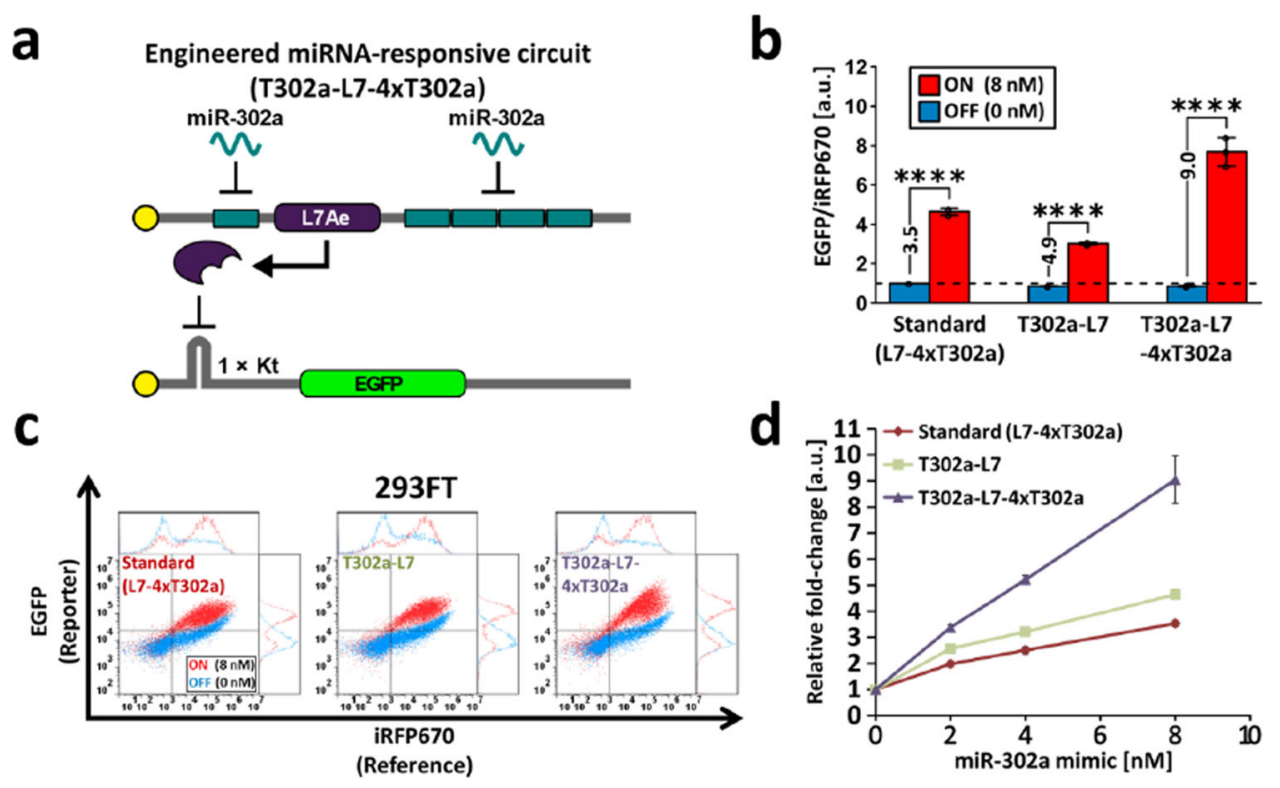

The HTML has been updated to include a corrected version of the Supplementary Information.

Published online: 26 April 2019

\begin{abstract}
(c) (i) Open Access This article is licensed under a Creative Commons Attribution 4.0 International License, which permits use, sharing, adaptation, distribution and reproduction in any medium or format, as long as you give appropriate credit to the original author(s) and the source, provide a link to the Creative Commons license, and indicate if changes were made. The images or other third party material in this article are included in the article's Creative Commons license, unless indicated otherwise in a credit line to the material. If material is not included in the article's Creative Commons license and your intended use is not permitted by statutory regulation or exceeds the permitted use, you will need to obtain permission directly from the copyright holder. To view a copy of this license, visit http://creativecommons.org/licenses/by/4.0/.
\end{abstract}

(C) The Author(s) 2019 